\title{
Sorption of cadmium, zinc and copper in dominant soils of the Zagreb aquifer system, Croatia
}

\author{
Zoran Kovač ${ }^{1}$, Stanko Ružičić1,*, Vedran Rubinić ${ }^{1}$, Zoran Nakić ${ }^{1}$ and Marcel Sertić ${ }^{1}$ \\ 1 University of Zagreb, Faculty of Mining, Geology and Petroleum Engineering, Pierottijeva 6, 10000 Zagreb, Croatia; \\ ( ${ }^{*}$ corresponding author: stanko.ruzicic@rgn.unizg.hr) \\ 2 University of Zagreb, Faculty of Agronomy, Svetošimunska cesta 25, 10000 Zagreb, Croatia
}

doi: $10.4154 / g c .2022 .05$

\section{Article history:}

Manuscript received April 20, 2021

Revised manuscript accepted October 06, 2021

Available online January 31, 2022

Keywords: sorption, PTMs, soil contamination Fluvisols, Gleysols, Cambisols, Zagreb aquifer system

\begin{abstract}
Contamination of soils with potentially toxic metals (PTMs) is an environmental problem. In this study, sorption of cadmium (Cd), zinc ( $\mathrm{Zn}$ ) and copper ( $\mathrm{Cu}$ ) in four soil profiles (two Fluvisols, one Gleysol, and one Cambisol), representing the dominant soils of the Zagreb aquifer system, were studied using a multi element laboratory batch test. Mathematical expressions were applied to establish the relationship between the concentration of the adsorbent in the liquid phase and the solid phase at equilibrium and in laboratory conditions. The study revealed that the investigated soils have a higher capacity to sorb $\mathrm{Cu}$ than $\mathrm{Zn}$ and $\mathrm{Cd}$. The most significant physicochemical characteristics of soils, influencing sorption, are $\mathrm{pH}$, carbonate content (minerals) and organic matter. Although all PTMs in all analyzed soils had a similar sorption capacity, the variation of sorption was higher in the siltic soils (Fluvisols) compared with the texturally finer (loamic) Gleysol and Cambisol soils, as well as in the subsoil horizons compared with the topsoils. Results indicate that sorption of PTMs is more influenced by physicochemical characteristics at different soil depths than by soil type, which is confirmed with a higher affinity for $\mathrm{Zn}$ and $\mathrm{Cd}$ bonding in the topsoil horizons. Also, it has been shown that $\mathrm{Cd}$ may pose more of a threat to soils and groundwater due to its toxicity and relatively high mobility in comparison with $\mathrm{Zn}$ and $\mathrm{Cu}$.
\end{abstract}

\section{INTRODUCTION}

Water and soil may be polluted with potentially toxic metals (PTMs) as a result of human activities, such as metal mining and smelting, industrial and energy production, land application, waste disposal practices, or by accident. Accumulated PTMs in soils can be transported through the soil into the groundwater, thus causing deterioration of quality of groundwater used for human consumption. In this study, four soil profiles located in the area of the Zagreb aquifer system (Croatia) were sampled and analyzed. According to NAKIĆ et al. (2013), PTMs, nitrates, pesticides, pharmaceuticals and chlorinated aliphatics are the main contaminants of groundwater within the Zagreb aquifer system.

In this study, we assessed the extent of retention of three PTMs by soils having a wide range of properties such as cation exchange capacity (CEC), organic matter $(\mathrm{OM})$, soil texture, $\mathrm{pH}$, electrical conductivity (EC) and carbonate content. The PTMs selected were $\mathrm{Cd}, \mathrm{Cu}$, and $\mathrm{Zn}$.

Cadmium (Cd) is one of the most toxic elements with carcinogenic and teratogenic impacts (LICHNER et al., 2006). Anthropogenic activities such as mining, P-fertilizers, and atmospheric deposition are conventional sources of soil Cd pollution (SMOLDERS \& MERTENS, 2013). Because of its toxicity and relatively high mobility in soil, the behaviour and transport of $\mathrm{Cd}$ are more widely studied compared to other heavy metals. Most studies are concerned with the fate and transport of $\mathrm{Cd}$ in soils under defined laboratory conditions (SEUNTJENS et al., 2001). However, more recently, Cd sorption and transport have been addressed under natural field conditions (ELBANA et al., 2018). According to their results, $\mathrm{Cd}$ adsorption isotherms illustrate the weak or moderate sorption of $\mathrm{Cd}$ in the analyzed soils.
Zinc $(\mathrm{Zn})$ is an essential nutrient which can be toxic in large amounts (NAN et al., 2002). Several heavy metals such as Zn, $\mathrm{Mo}$ and $\mathrm{Cu}$ are essential micronutrients required in the growth of both plants and animals. Micronutrients are often applied in the form of fertilizers or as supplements in animal feed (ELBANA et al., 2018). Therefore, the amount of $\mathrm{Zn}$ added to the soils in agricultural practices is substantial (BONTEN et al., 2008). Sorption of $\mathrm{Zn}$ in soils is widely studied using laboratory conditions. DIŞLI (2010) studied batch and column sorption of $\mathrm{Cu}, \mathrm{Zn}$, and $\mathrm{Mn}$ in alluvial sediments and soils. According to his investigations, $\mathrm{Cu}$ is the most strongly sorbed metal by alluvial soils.

HOUGH (2010) considered that copper $(\mathrm{Cu})$ is an essential micronutrient for human life and health, as well as for plants. Copper compounds are widely used as fungicidal and bactericidal sprays, fertilizers, and stimulants of animal growth (PIETRZAK \& McPHAIL, 2004). Prolonged use of Cu-based chemicals often results in soil contamination (PIETRZAK \& McPHAIL, 2004; BESNARD et al., 2001). TRAKAL et al. (2012) studied copper sorption on soil materials using batch laboratory experiment. They found that $\mathrm{Cu}$ sorption is predominantly controlled by OM content.

Potentially toxic metals form the important group of substances causing contamination of soil and groundwater. These elements may become toxic to plants and animals if their concentrations exceed certain values (ADRIANO, 2001). Contamination with PTMs in soil may be geogenic or anthropogenic origin. Geogenic sources of PTMs (e.g. Cd, Cr, Pb and Zn) include parent rock, volcanic eruptions, deposition by wind or water, while anthropogenic sources include fertilizers, pesticides, sewage waste water, traffic, landfills, metallurgy, mining, etc. (RULEY et al., 
2006). Potential sources of contamination in the studied soil profiles are industrial plants, traffic, airport and agriculture.

Soil can immobilize and thereby reduce the migration of PTMs in its deeper parts, depending on the soil and the contaminants characteristics. The study of sorption properties of the soil is important because it can help to better understand processes of PTM transport through soil and consequently groundwater.

Adsorption processes are often influenced by various soil parameters, which are difficult to measure. The two empirical models most frequently used to describe PTM adsorption in/or on soil components are the Freundlich and Langmuir isotherms. These simple models are often used to express laboratory sorption data if specific models are lacking. Adsorption of $\mathrm{Cu}, \mathrm{Cd}$ and $\mathrm{Zn}$ onto various soils and sediments was modelled by researchers using the Freundlich and Langmuir isotherms (JALALI \& MOHARRAMI, 2007; VEGA et al., 2001; SIPOS, 2009; ELBANA \& SELIM, 2019; HE et al., 2020). SIPOS (2009) studied sorption of $\mathrm{Cu}$ and $\mathrm{Zn}$ on a silty loam type of soil. The authors concluded that affinities of metals towards the soil samples from different horizons followed the same sequence, i.e. $\mathrm{Pb} \geq \mathrm{Cu}>\mathrm{Zn}$.

VEGA et al. (2008) studied the sorption of $\mathrm{Cu}, \mathrm{Pb}$ and $\mathrm{Cd}$, from single and multi-element solutions. They concluded that sorption of $\mathrm{Cu}$ is higher than $\mathrm{Cd}$ sorption.

$\mathrm{Cu}$ and $\mathrm{Zn}$ are often regarded as strongly sorbed metals by soils in comparison to $\mathrm{Cd}$. The sorption of $\mathrm{Cu}$ and $\mathrm{Zn}$ is correlated significantly with soil $\mathrm{pH}, \mathrm{OM}$, cation exchange capacity (CEC), amorphous oxides, and clay content (ADRIANO, 2001; SHAHEEN et al., 2009). Also, soil pH can have the greatest effect of any single parameter on the mobility or retention of metals, with a greater retention and lower solubility of metal cations that occur at high soil pH (MARTINEZ \& MOTTO, 2000). APPEL \& MA (2002) suggested that Cd sorption was pH-dependent and could involve electrostatic surface reactions and/or innersphere complexation.

Numerous studies of contamination of soils and sediments with PTMs have been carried out in the area of the Zagreb aquifer system (DURN et al., 1999; ROMIĆ \& ROMIĆ, 2003; SOLLITO et al., 2010). According to DURN et al. (1999), high contents of $\mathrm{Pb}, \mathrm{Hg}$, and $\mathrm{Zn}$ in the topsoils of the northern lowland residential parts of Zagreb have been attributed only to fossil fuel consumption and the flooding of the Sava River. ROMIC \& ROMIĆ (2003) found that copper is characterized by a strongly scattered anthropogenic influence, particularly related to the uncontrolled waste dumps of liquid waste from households or agricultural enterprises. In addition, the same authors concluded that part of the area with the highest determined concentrations of $\mathrm{Zn}$, $\mathrm{Pb}$ and $\mathrm{Cd}$ was repeatedly flooded.

Hence, the recent sedimentation of the river deposits exposed to pollution is a very probable cause of the accumulation of metals in an inundation area. According to SOLLITO et al. (2010), variation in the metal concentrations in the topsoil of the Zagreb area has both natural and anthropogenic origins. In all the aforementioned studies, PTMs were analyzed without using sorption modelling.

RUŽIČIĆ et al. (2016), studied the sorption of Pb, Zn and $\mathrm{Cd}$ in Fluvisols. The highest sorption was determined in surface horizons with higher CEC, while the difference in sorption between individual metals was small. In addition, RUŽIČIĆ \& JAŠARAGIĆ-RAKO (2017) found that the sorption of Pb, Cd, $\mathrm{Cu}$ and $\mathrm{Zn}$ decreases with depth in Fluvisols.
Our research enabled comparison of the sorption parameters of selected PTMs in two texturally different soil types. The main objectives of the investigation were: (1) to determine the sorption characteristics of $\mathrm{Zn}, \mathrm{Cu}$ and $\mathrm{Cd}$, using batch laboratory experiments; (2) to build PTM isotherms, valid for the investigated soils types; (3) to gain information about the sorption affinities of selected PTMs for the investigated soils and between topsoil (shallow) and subsoil (deep) horizons; (4) to estimate the potential of groundwater contamination in the study area by selected PTMs.

\section{MATERIALS AND METHODS}

\subsection{Study area, investigated soils, field work}

The study area is situated in NW Croatia (Fig. 1), covering 350 $\mathrm{km}^{2}$, including the Zagreb metropolitan area with its surroundings. The relief is flat and low, while the climate is humid continental, with annual means for precipitation and temperature of around $850 \mathrm{~mm}$ and $11{ }^{\circ} \mathrm{C}$, respectively. Natural vegetation, which generally consists of meadows and deciduous forests, is largely cleared for agricultural land use. Three types of deposits dominate in the Zagreb aquifer system: sands, gravels and silts/ silty clays, deposited mainly during the Pleistocene and Holocene (VELIĆ \& SAFTIĆ, 1991). On these deposits, several types of soil have formed, with Fluvisols and Eutric Fluvic Cambisols as the dominant ones, and Gleysols and Fluvic Phaeozems as subordinate soils (IUSS WORKING GROUP WRB, 2014).

Fluvisols form a belt a few $\mathrm{km}$ wide along the Sava River (as well as some narrow belts along the smaller streams). Given that most of these soils have been protected from flooding, they now have a moderately developed A (or Ap) horizon overlying several fluvial layers that are often separated one from another by a lithic discontinuity. In some specific the A horizon is fully developed, and Fluvisols grade into Fluvic Phaeozems. Fluvisols of the area are largely well-drained loams (or even sandy loams) with highly fluctuating groundwater that may rise into the top $1 \mathrm{~m}$ of the soil profile. Generally, they are calcareous throughout and accordingly, slightly alkaline.

Gleysols are poorly drained soils that are saturated with surface water and/or groundwater for long enough periods in order to develop reducing conditions and gleyic properties, which characterize their morphology. They form in the low-lying landscape positions, which enable prolonged ponding and/or high groundwater table levels, where they are often associated with Fluvic Stagnic Phaeozems. Both these soils usually have a notably finer texture in comparison with Fluvisols and Fluvic Phaeozems.

Eutric Fluvic Cambisols have a B horizon (cambic horizon) underlying the A horizon. Cambic horizons are diagnosed due to the evidence of pedogenic alteration, (removal of carbonates, soil structure formation, increase in clay and/or Fe content, etc.). Cambisols in the study area are mainly loams or clay loams with good drainage. In general, they are non-calcareous, neutral to slightly acid (by definition having a $\mathrm{pH}>5.5$ ).

Field research was conducted on four soil profiles (Fig. 1). According to the WRB system, profiles 1 and 2 were classified as Fluvisols, Profile 3 as a Gleysol, and Profile 4 as a Cambisol. As expected, the Fluvisols were texturally finer (siltic) than the two remaining soils (loamic). Profile 1 is a Calcaric Fluvisol (Siltic) with the following horizon sequence according to FAO (2006): A-AC-2Cl-3Cl-4Clr/Cl-5Clr. Profile 2 is a Calcaric Fluvisol (Humic, Siltic), with horizons A-2AC1-2AC2-3C1-3C24AC-5AC-5C. Profile 3 is a Calcaric Fluvic Stagnic Gleysol (Abruptic, Hyperhumic, Loamic): A-2Ag-2Ag2-2ACg-3ACl, whereas 


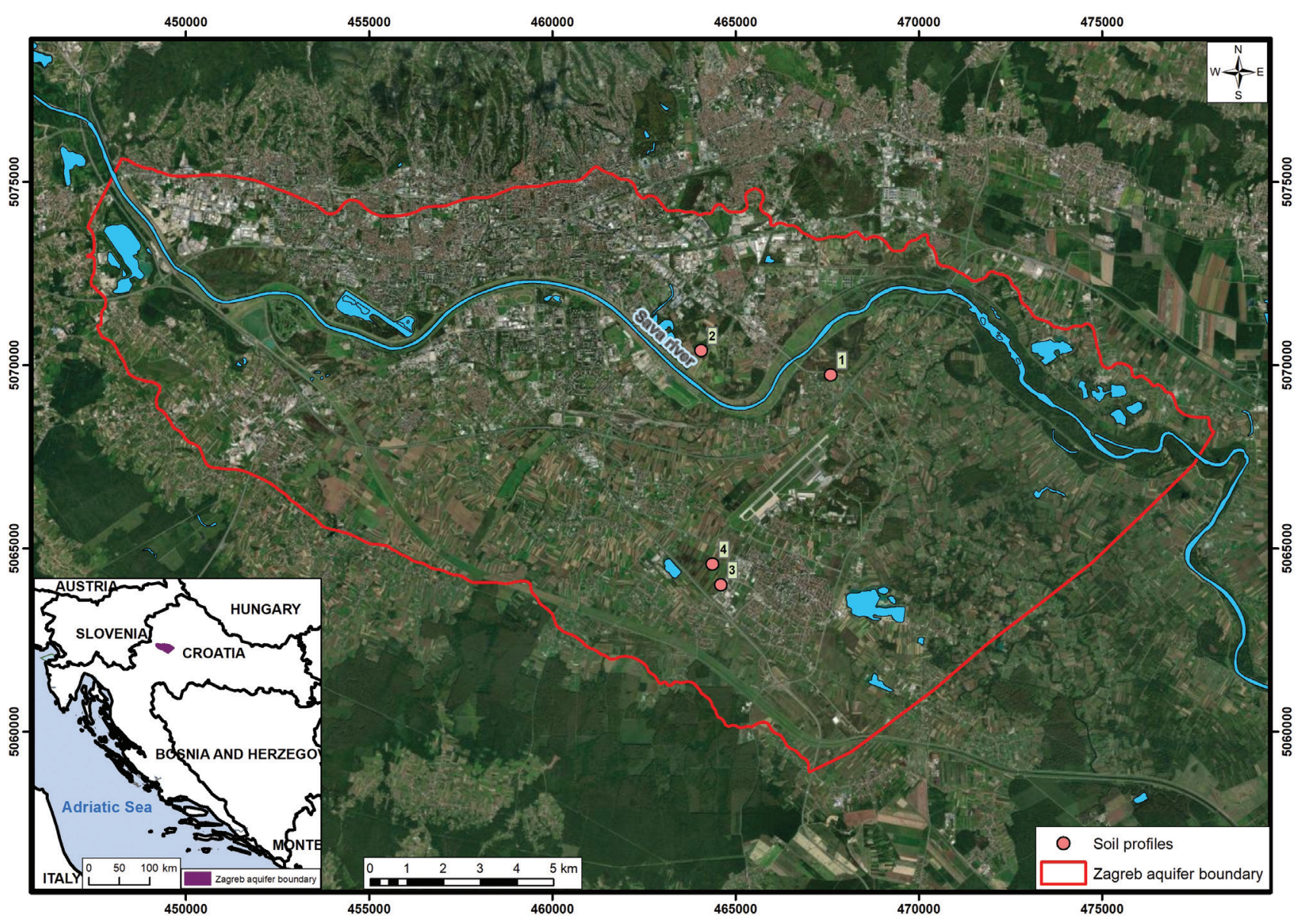

Figure 1. Zagreb aquifer boundary with the location of soil profiles.

the Profile 4 is a Eutric Fluvic Cambisol (Loamic, Raptic): A-2B3BC.

At the Profile 1 site, a pedological pit was excavated up to $210 \mathrm{~cm}$ deep and detailed sampling and soil descriptions were undertaken (RUŽIČIĆ et al., 2016). A similar field investigation was conducted at the Profile 4 site. There, the soil is $90 \mathrm{~cm}$ deep. Regarding soil profiles 2 and 3, the field research consisted of borehole drilling using an auger probe (instead of pit excavation). Soil profiles 2 and 3 are 190 and $110 \mathrm{~cm}$ deep respectively. In total, 22 bulk soil samples for laboratory analyses and experiments were collected from the four soil profiles.

\subsection{Methods}

Soil samples were air-dried and passed through a $2 \mathrm{~mm}$ sieve for laboratory analyses and experiments. Soil $\mathrm{pH}$ was measured in the potassium chloride solution $(\mathrm{KCl})$ with a 1:2.5 soil to solution ratio (ISO 13536, 2005) using WTW 340 and a pH meter. The electrical conductivity of soils was measured in water with a 1:5 soil to water ratio using a Mettler Toledo MPC 227 EC meter. Carbonate content was determined gas-volumetrically using a Scheibler apparatus (HEAD, 1992), while organic matter was determined using hydrogen peroxide solution. The cation exchange capacity (CEC) was determined using barium chloride solution (ISO 13536, 1995).

Sorption isotherms for the soluble forms of copper $(\mathrm{Cu})$, cadmium (Cd), and zinc ( $\mathrm{Zn}$ ) were established for twenty-two bulk soil samples. The experiment was conducted with three replicates with relative standard deviation of $5 \%$. Sorption isotherms were obtained for each soil sample by equilibrating $0.5 \mathrm{~g}$ soil with
$50 \mathrm{ml}$ of solutions containing concentrations of 10, 20,30, 40 and $50 \mathrm{mg} / \mathrm{l}$ of all the analyzed elements in the same concentrations. PTMs were added to the solutions in the form of sulphates $\left(\mathrm{CuSO}_{4} \times 5 \mathrm{H}_{2} \mathrm{O}, \mathrm{ZnSO}_{4}\right)$, and chloride $\left(\mathrm{CdCl}_{2}\right)$. Soils were equilibrated for $24 \mathrm{~h}$ by shaking at room temperature. Suspensions were then centrifuged at $3000 \mathrm{rpm}$ for $20 \mathrm{~min}$, and the PTM concentrations in the equilibration solution were measured by atomic absorption spectrometry (AAS) (instrument Perkin Elmer AAnalyst 700). The amount of PTMs sorbed by the soil was calculated using the following equation according to OECD (2000):

$$
S=\frac{\left(c_{o}-c_{e}\right) \times V}{W}
$$

where $S$ is the adsorbed amount of metal per unit weight of soil $(\mathrm{mg} / \mathrm{g}), c_{0}$ the initial concentration of metal in the solution $(\mathrm{mg} / \mathrm{l})$, $c_{e}$ the equilibrium concentration of metal in the solution $(\mathrm{mg} / \mathrm{l})$, $V$ the solution volume (l) and $W$ the weight of air-dried soil (g).

The corresponding sorption isotherms for each PTM were quantitatively described by parameters through fitting the experimental data to the Freundlich isotherms.

A simple linear relationship between the solution and adsorbed phases can be described by the equation:

$$
S=K_{d} c_{e}
$$

where $S$ is the amount of solute adsorbed onto the solid phase $(\mathrm{mg} / \mathrm{g}), K_{d}$ the slope of the isotherm, often referred to as the distribution coefficient $(1 / \mathrm{g})$. 


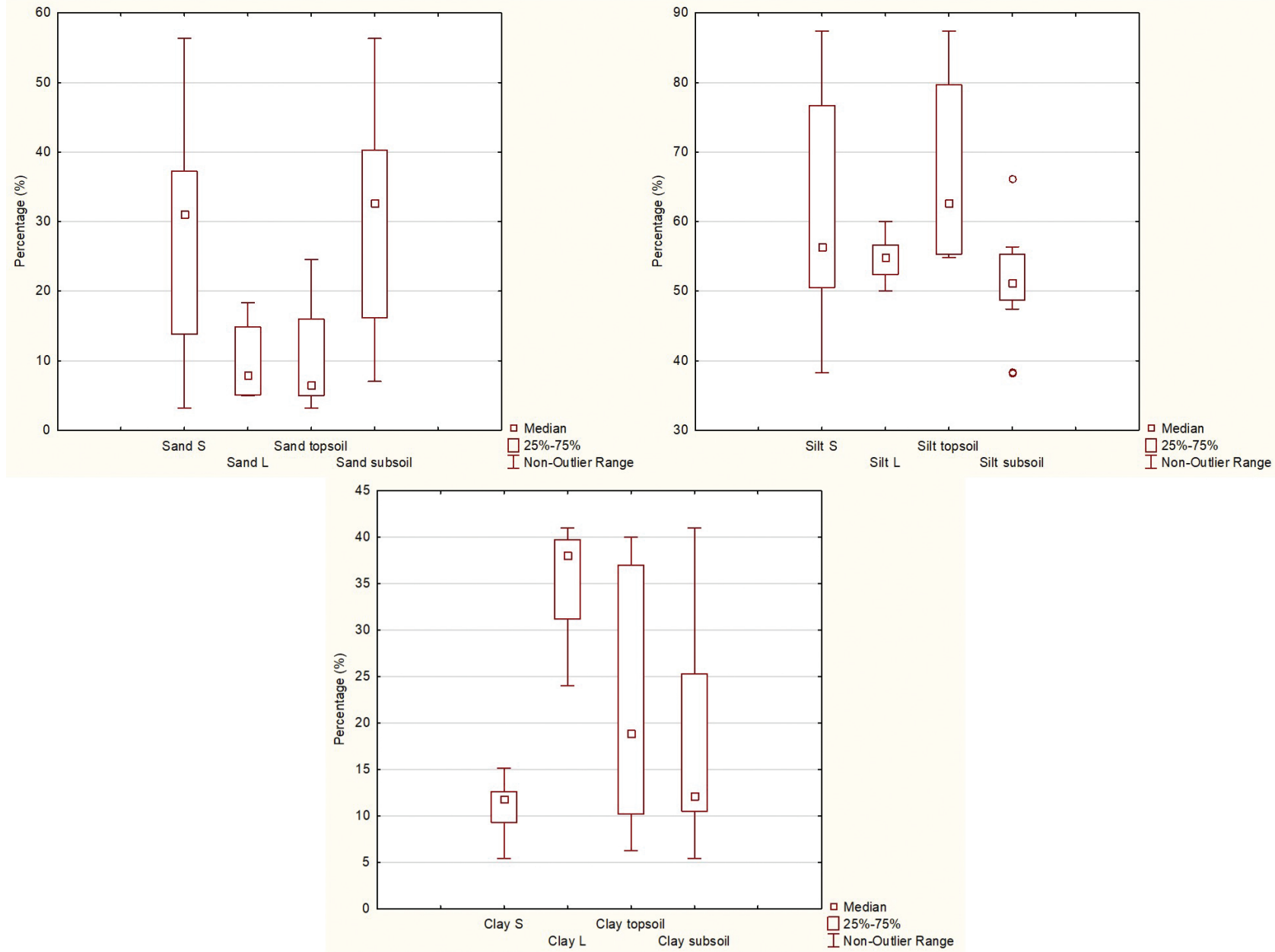

Figure 2. Box plots of sand, silt and clay content in siltic soils (S), loamic soils (L), topsoil (shallow) and subsoil (deep) horizons.

The basic form of the Freundlich isotherm equation is defined as follows:

$$
S=K_{f} c_{e}^{a}
$$

where $K_{f}(\mathrm{l} / \mathrm{g})$ is a partitioning coefficient and is a measure of the affinity of a heavy metal to a soil and is widely reported in the literature for various chemicals. The parameter $a$ is dimensionless and provides information on the degree of heterogeneity of the sorption sites (SELIM et al., 1992). As $a$ approaches 0, surface site heterogeneity increases, and as $a$ approaches 1 surface site homogeneity also increases.

The relative sorption capacity (RSC) was also used to compare the metal sorption capacity of the samples (XIONG et al., 2005). The RSC can be calculated by taking the difference between the initial and equilibrium metal concentrations, then dividing this difference by the initial metal concentration, and then expressing this as a percentage:

$$
R S C=\frac{\left(c_{o}-c_{e}\right)}{c_{o}} \cdot 100
$$

All parameters were evaluated using descriptive statistics, namely minimum, maximum, average values, median, box-plots and correlation analysis using Statistica 13.5.0.17. (TIBCO Software Inc., 1984-2018).

Calculation of isotherms was undertaken in Microsoft ${ }^{\odot} \mathrm{Ex}-$ cel. A research area map (Fig.1) was produced in ArcMap 10.1 and a geocoded terrain (orthophoto) image was obtained from the geoportal of the Croatian Geodetic Administration.
Table 1. Selected physicochemical properties of the investigated soils. Electrical

\begin{tabular}{|c|c|c|c|c|c|c|}
\hline $\begin{array}{c}\text { Soil } \\
\text { profiles }\end{array}$ & $\begin{array}{c}\text { Soil } \\
\text { horizons }\end{array}$ & $\begin{array}{l}\text { OM } \\
(\%)\end{array}$ & $\begin{array}{c}\mathrm{pH} \\
(\mathrm{KCl})\end{array}$ & $\begin{array}{c}E C \\
(\mu S / \mathrm{cm})\end{array}$ & $\begin{array}{c}\text { Carbonates } \\
\text { (mass. \%) }\end{array}$ & $\begin{array}{c}\text { CEC } \\
(\mathrm{meq} / 100 \mathrm{~g})\end{array}$ \\
\hline \multirow{6}{*}{$\begin{array}{l}\text { Profile } 1 \\
\text { (F) }\end{array}$} & $\mathrm{A}$ & 6.32 & 7.28 & 173 & 34.12 & 18.47 \\
\hline & $A C$ & 2.68 & 7.37 & 129 & 35.02 & 18.51 \\
\hline & $2 \mathrm{Cl}$ & 1.17 & 7.36 & 89 & 41.29 & 8.11 \\
\hline & $3 \mathrm{Cl}$ & 1.25 & 7.39 & 99 & 41.29 & 9.56 \\
\hline & $4 \mathrm{Clr} / \mathrm{Cl}$ & 1.25 & 7.47 & 74 & 40.24 & 10.16 \\
\hline & $5 \mathrm{Cr}$ & 1.42 & 7.45 & 91 & 42.99 & 10.67 \\
\hline \multirow{8}{*}{$\begin{array}{c}\text { Profile } 2 \\
\text { (F) }\end{array}$} & A & 8.86 & 7.34 & 197.9 & 18.76 & 26.19 \\
\hline & $2 \mathrm{ACl}$ & 2.84 & 7.34 & 131.5 & 20.82 & 25.72 \\
\hline & $2 A C 2$ & 3.1 & 7.47 & 155.1 & 24.66 & 23.67 \\
\hline & $3 \mathrm{Cl}$ & 1.05 & 7.52 & 170.7 & 32.31 & 22.66 \\
\hline & $3 C 2$ & 0.75 & 7.58 & 139.5 & 34.12 & 22.22 \\
\hline & $4 A C$ & 4.97 & 7.53 & 164 & 34.6 & 23.26 \\
\hline & $5 A C$ & 3.03 & 7.60 & 103.3 & 36.1 & 23.15 \\
\hline & $5 C$ & 0.77 & 7.66 & 139.7 & 34.76 & 22.79 \\
\hline \multirow{5}{*}{$\begin{array}{c}\text { Profile } 3 \\
\text { (C) }\end{array}$} & $A$ & 8.98 & 6.36 & 147.2 & 16.77 & 34.43 \\
\hline & $2 \mathrm{Ag}$ & 10.18 & 6.57 & 287 & 15.9 & 31.74 \\
\hline & $2 \mathrm{Ag} 2$ & 9.19 & 7.05 & 286.33 & 22.94 & 37.48 \\
\hline & $2 \mathrm{ACg}$ & 7.97 & 6.93 & 364.67 & 21.25 & 24.63 \\
\hline & $3 \mathrm{ACl}$ & 7.16 & 6.47 & 395 & 6.73 & 19.55 \\
\hline \multirow{7}{*}{$\begin{array}{c}\text { Profile } 4 \\
\text { (C) }\end{array}$} & A & 5.35 & 6.49 & 117.27 & 1.10 & 29.01 \\
\hline & $2 B$ & 2.07 & 5.36 & 49.83 & 0.80 & 28.74 \\
\hline & $3 B C$ & 3.32 & 5.74 & 58.07 & 0.75 & 21.50 \\
\hline & Average & 4.26 & 7.12 & 162.97 & 25.31 & 22.37 \\
\hline & Median & 3.07 & 7.35 & 140.15 & 28.49 & 22.97 \\
\hline & Maximum & 10.18 & 7.66 & 395.00 & 42.99 & 37.48 \\
\hline & Minimum & 0.75 & 5.90 & 49.80 & 0.70 & 8.11 \\
\hline
\end{tabular}
conductivity (EC); cation exchange capacity (CEC); organic matter (OM). 

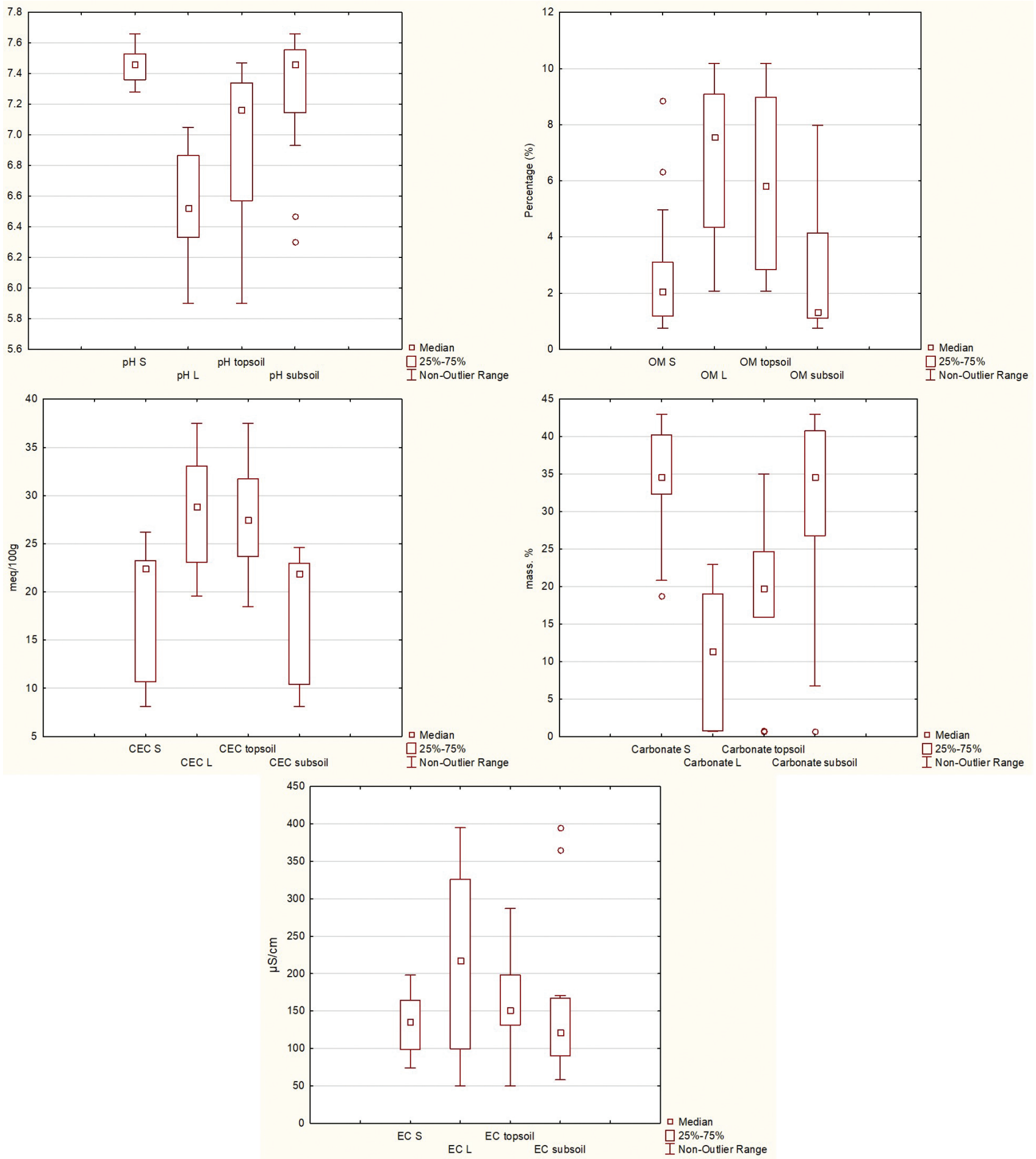

Figure 3. Box plots of OM, pH, CEC, EC and carbonate content in siltic soils (S), loamic soils (L), topsoil (shallow) and subsoil (deep) horizons.

\section{RESULTS}

\subsection{Soils characterization}

Results of the particle size analysis (soil texture) for the investigated soil profiles were previously published in RUŽIČIĆ et al. (2019a). The sand content varies from $3.18 \%$ to $56.33 \%$, while silt content ranges from $38.23 \%$ to $87.43 \%$, and the clay content varies from $5.44 \%$ to $41 \%$. Average percentages for sand, silt and clay contents are $21.69 \%, 58.67 \%$ and $19.65 \%$, while the median values are $17.15 \%, 55.17 \%$ and $12.96 \%$ respectively (RUŽIČIĆ et al., 2019a). Comparing particle size distribution between different soil types and between topsoil and subsoil horizons, it can be seen (Fig. 2) that the sand content is the highest in siltic soils (S) and in subsoil horizons. Silt content is the highest in siltic soils and in the topsoil horizons, while clay content is the highest in loamic soils (L) and in topsoil horizons (Fig. 2).

Physicochemical characteristics of the analyzed soils are summarized in Table 1. OM varies from $0.75 \%$ to $10.18 \%$, with average and median values of $4.26 \%$ and $3.07 \%$, respectively. Values of $\mathrm{pH}$ range from 5.90 to 7.66, with average and median values of 7.12 and 7.35. CEC values range from $8.11 \mathrm{meq} / 100 \mathrm{~g}$ up to $37.48 \mathrm{meq} / 100 \mathrm{~g}$, with average and median values of 22.37 and $22.97 \mathrm{meq} / 100 \mathrm{~g}$. Carbonate content varies from $0.7 \%$ to 

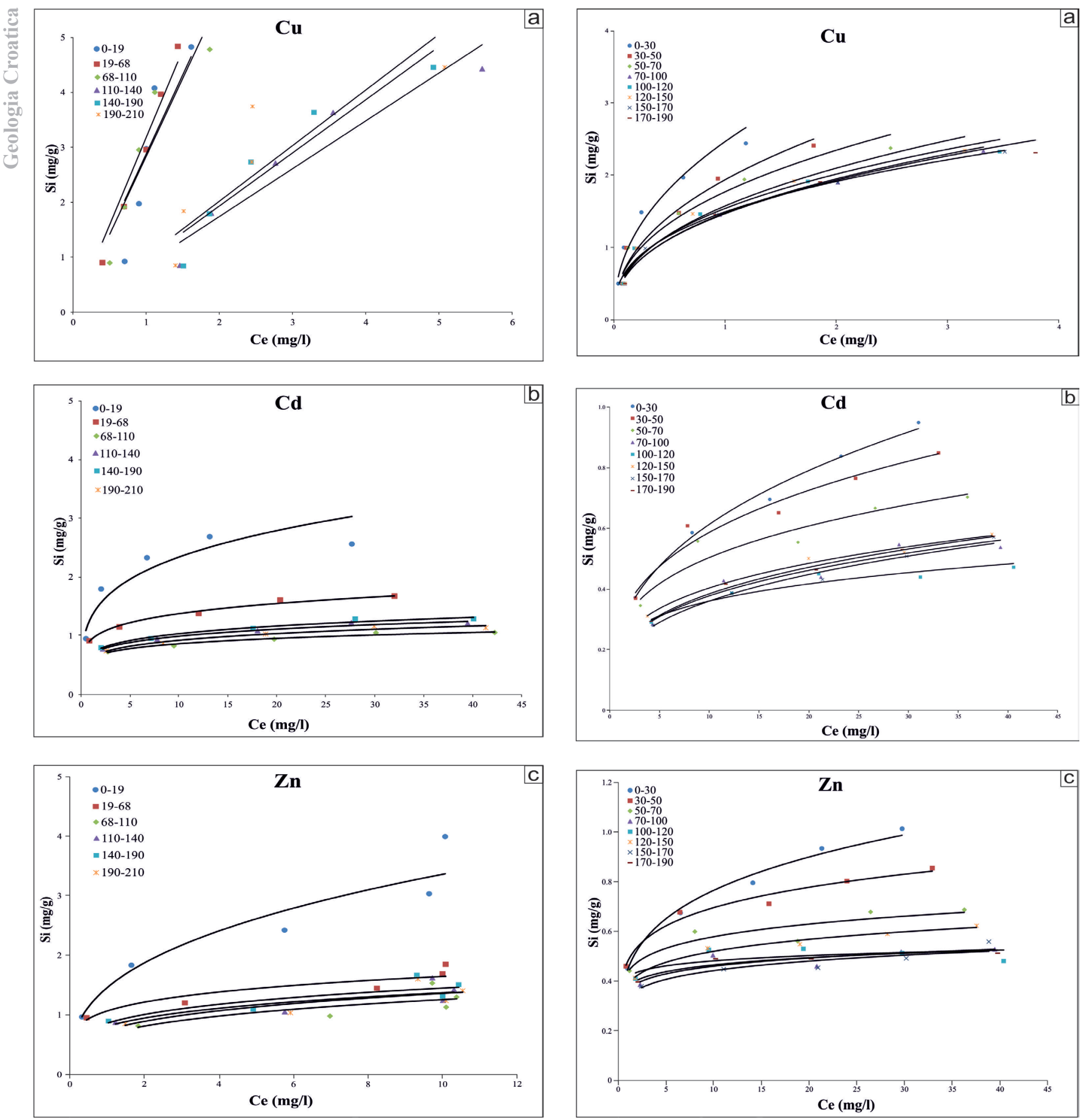

Figure 4. Freundlich sorption isotherms for Profile 1: a) $\mathrm{Cu}$; (b) $\mathrm{Cd}$; (c) $\mathrm{Zn}$.

$42.99 \%$, with average and median values of $25.31 \%$ and $28.49 \%$. EC values range from $49.80 \mu \mathrm{S} / \mathrm{cm}$ up to $395 \mu \mathrm{S} / \mathrm{cm}$ with average and median values of 162.97 and $140.15 \mu \mathrm{S} / \mathrm{cm}$.

Figure 3 . shows that $\mathrm{OM}$ values are significantly higher in loamic soils and in topsoil horizons in comparison with siltic soils and deeper horizons. A similar pattern can be observed for CEC values, although differences in $\mathrm{CEC}$ values between soil profiles and horizons are less pronounced. EC values are also higher in loamic soils and topsoil horizons, while the highest values of carbonates and $\mathrm{pH}$ are observed in siltic soils and in deeper horizons.

Organic matter $(\mathrm{OM})$ content of Profile 1 ranges from $1.17 \%$ $(68-110 \mathrm{~cm})$ to $6.32 \%(0-19 \mathrm{~cm})$. Its carbonate content (calcite and dolomite) ranges from $34.12 \%(0-19 \mathrm{~cm})$ to $42.99 \%(190-210 \mathrm{~cm})$.

Figure 5. Freundlich sorption isotherms for Profile 3: a) $\mathrm{Cu}$; (b) $\mathrm{Cd}$; (c) $\mathrm{Zn}$.

The highest CEC value was $18.5 \mathrm{meq} / 100 \mathrm{~g}$ in the two upper soil horizons of this profile, which is in line with the contents of $\mathrm{OM}$ (Table 1).

Content of OM in Profile 2 ranges from $0.75 \%(100-120 \mathrm{~cm})$ to $8.86 \%(0-30 \mathrm{~cm})$ and shows an irregular depth-related trend (Table 1). The highest CEC values (approx. $26 \mathrm{meq} / 100 \mathrm{~g}$ ) were determined in the two upper soil horizons, which is comparable with the results for Profile 1. Carbonate content (calcite and dolomite) in Profile 2 ranges from $18.76 \%(0-30 \mathrm{~cm})$ to $36.10 \%(150$ $170 \mathrm{~cm}$ ), generally increasing with depth and being in line with its distribution in the Profile 1 (Table 1). The siltic soils (Profiles 1 and 2) have a high content of carbonates which corresponds with their alkaline $\mathrm{pH}$ values, ranging from 7.28 to 7.66 . Electri- 

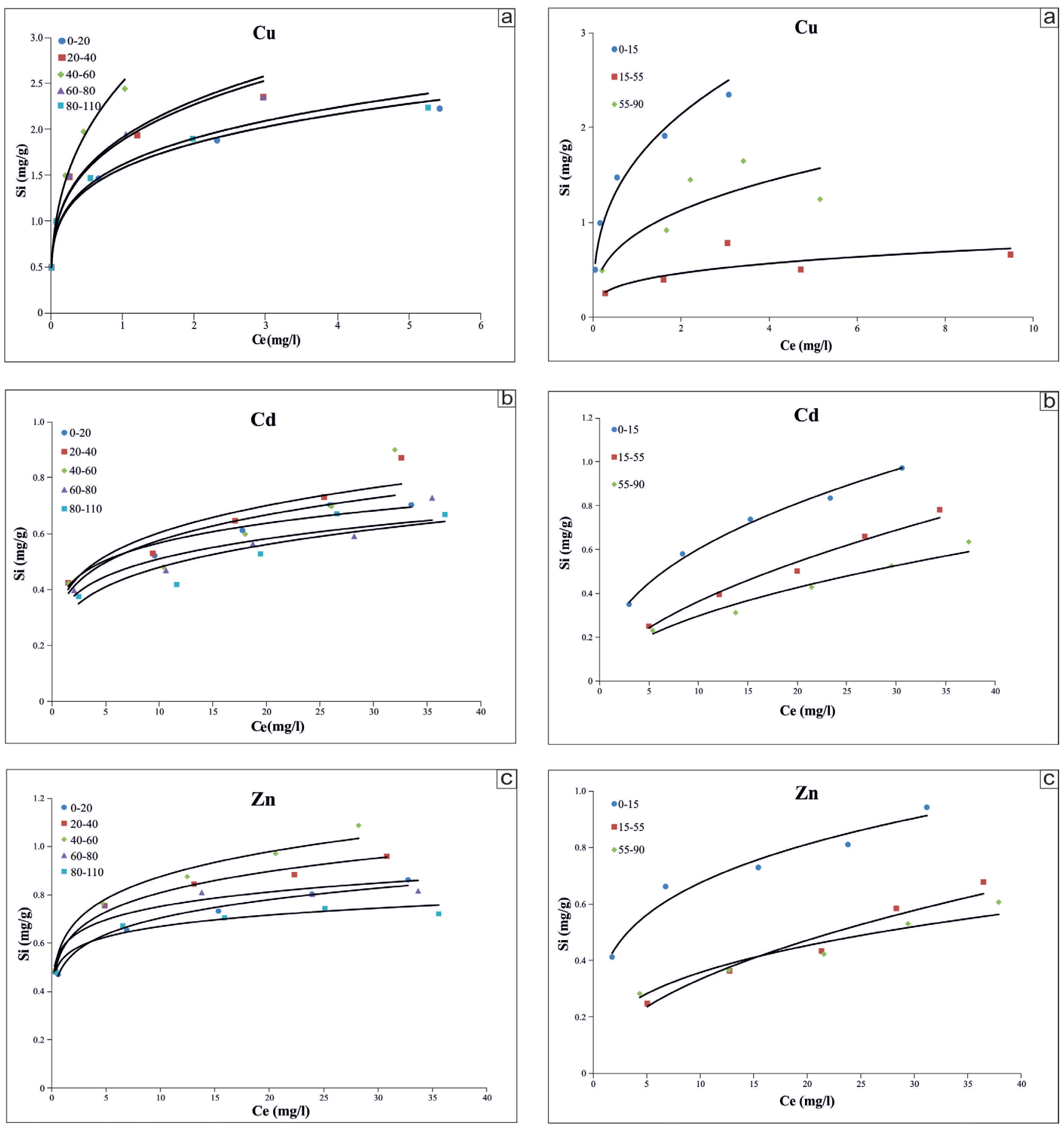

Figure 6. Freundlich sorption isotherms for Profile 3: a) Cu; (b) Cd; (c) Zn.

cal conductivity (EC) generally decreases with depth in these two soils (Table 1).

Distribution of OM in Profile 3 ranges from 7.16\% (80-110 $\mathrm{cm})$ to $10.18 \%(20-40 \mathrm{~cm})$ while through Profile 4 it ranges from $2.07 \%(15-55 \mathrm{~cm})$ to $5.35 \%(0-15 \mathrm{~cm})$ (Table 1). In the upper three horizons of profile 3 , the highest values of organic matter were measured, as well as the highest values of CEC, compared to other profiles. The high CEC values (approx. $29 \mathrm{meq} / 100 \mathrm{~g}$ ) were determined in the upper two soil horizons of the Profile 4 (Table 1). Carbonate content in Profile 4 is generally very low, being slightly higher in the topsoil $(1.10 \%)$ than in the underlying soil horizons (Table 1). This is not in line with results from Profile 3 (Table 1). In Profile 3, the content of carbonates increases

Figure 7. Freundlich sorption isotherms for Profile 4: a) Cu; (b) Cd; (c) Zn.

from the two topsoil horizons ( $16.8 \%$ and $15.9 \%$ ) to the two middle horizons (22.9\% and $21.3 \%)$, and then sharply decreases at the bottom of the profile (6.7\%). In comparison to the siltic soils, the loamic soils (profiles 3 and 4) have lower carbonate contents. Accordingly, they both have lower $\mathrm{pH}$ values - Profile 3 is slightly acid to neutral, whereas Profile 4 is slightly acid (Table 1). Also, in Profile 3, soil EC shows an increasing trend with soil depth, which is not the case in the remaining profiles (Table 1). EC distribution in Profile 4 is similar to Profiles 1 and 2 which can be matched with CEC values (Table 1).

\subsection{Sorption of PTMs}

Results of the competitive batch sorption experiments for all soil profiles are shown in Table 2 and Figures 4-7. Based on the results 
Table 2. Freundlich adsorption parameters for the analyzed PTMs.

\begin{tabular}{|c|c|c|c|c|c|c|c|}
\hline \multicolumn{2}{|c|}{ Profiles } & \multicolumn{2}{|c|}{$\mathrm{Cu}$} & \multicolumn{2}{|c|}{$\mathrm{Zn}$} & \multicolumn{2}{|c|}{$\mathrm{Cd}$} \\
\hline & $\begin{array}{l}\text { Depth } \\
(\mathrm{cm})\end{array}$ & $\begin{array}{c}\mathrm{K}_{\mathrm{f}}\left({ }^{*} \mathrm{~K}_{\mathrm{d}}\right) \\
(\mathrm{I} / \mathrm{g})\end{array}$ & $\mathrm{R}^{2}$ & $\mathrm{~K}_{\mathrm{f}}(\mathrm{I} / \mathrm{g})$ & $\mathrm{R}^{2}$ & $\mathrm{~K}_{\mathrm{f}}(\mathrm{I} / \mathrm{g})$ & $R^{2}$ \\
\hline \multirow{6}{*}{ Profile 1} & A & $2.882^{*}$ & 0.76 & 1.4559 & 0.95 & 1.3033 & 0.90 \\
\hline & AC & $3.1831^{*}$ & 0.96 & 1.0658 & 0.89 & 0.9293 & 0.99 \\
\hline & $2 \mathrm{Cl}$ & $2.8387^{*}$ & 0.86 & 0.6732 & 0.67 & 0.618 & 0.97 \\
\hline & $3 \mathrm{Cl}$ & $0.8708^{*}$ & 0.90 & 0.8081 & 0.89 & 0.6793 & 0.98 \\
\hline & $4 \mathrm{Clr} / \mathrm{Cl}$ & $0.9665^{*}$ & 0.90 & 0.8603 & 0.80 & 0.6972 & 0.98 \\
\hline & $5 \mathrm{Cr}$ & $1.0113^{*}$ & 0.70 & 0.7434 & 0.75 & 0.6268 & 0.97 \\
\hline \multirow{8}{*}{ Profile 2} & A & 2.4658 & 0.95 & 0.4472 & 0.99 & 0.2634 & 0.99 \\
\hline & $2 \mathrm{ACl}$ & 1.9378 & 0.91 & 0.4803 & 0.98 & 0.2897 & 0.96 \\
\hline & $2 \mathrm{AC2}$ & 1.7707 & 0.92 & 0.4375 & 0.86 & 0.2699 & 0.91 \\
\hline & $3 \mathrm{Cl}$ & 1.477 & 0.95 & 0.3654 & 0.78 & 0.1935 & 0.93 \\
\hline & $3 C 2$ & 1.5403 & 0.94 & 0.4176 & 0.51 & 0.2218 & 0.95 \\
\hline & $4 A C$ & 1.5746 & 0.94 & 0.3869 & 0.98 & 0.2191 & 0.99 \\
\hline & $5 A C$ & 1.4929 & 0.99 & 0.3356 & 0.88 & 0.1748 & 0.98 \\
\hline & $5 C$ & 1.4676 & 0.95 & 0.3804 & 0.92 & 0.1943 & 0.99 \\
\hline \multirow{5}{*}{ Profile 3} & A & 1.576 & 0.98 & 0.5021 & 0.99 & 0.3844 & 0.95 \\
\hline & $2 \mathrm{Ag}$ & 1.8821 & 0.98 & 0.5742 & 0.99 & 0.3676 & 0.90 \\
\hline & $2 \mathrm{Ag} 2$ & 2.5159 & 0.99 & 0.6054 & 0.99 & 0.3536 & 0.75 \\
\hline & $2 \mathrm{ACg}$ & 1.9118 & 0.98 & 0.5834 & 0.93 & 0.3293 & 0.88 \\
\hline & $3 \mathrm{ACl}$ & 1.614 & 0.99 & 0.5346 & 0.97 & 0.2846 & 0.82 \\
\hline \multirow{3}{*}{ Profile 4} & A & 1.6695 & 0.97 & 0.3663 & 0.97 & 0.2274 & 0.99 \\
\hline & $2 B$ & 0.38 & 0.74 & 0.1058 & 0.97 & 0.0953 & 0.99 \\
\hline & $3 B C$ & 0.8821 & 0.83 & 0.1634 & 0.95 & 0.0899 & 0.96 \\
\hline
\end{tabular}

of sorption experiments, Freundlich's parameter and coefficients of determination (R-squared) for selected PTMs were calculated.

In Fig. 8 it can be seen that the sorption values capacity of all PTMs have greater variability in siltic soils and in the subsoil horizons. However, outliers are only present for all PTMs in topsoil horizons. If median sorption values are examined based on the type of soil and depth, separately for each PTM, it can be seen that there is only a small difference. However, it can be seen that the median values of $\mathrm{Cu}$ sorption are approximately twice as high as the median values of the sorption of $\mathrm{Zn}$ and $\mathrm{Cd}$.

In Tables 4 and 5, correlation analyses of soil texture parameters, physicochemical characteristics and sorption parameters are shown for all the analyzed soils.

In siltic soils (Table 4) it can be seen that the sorption parameters of selected PTMs are negatively correlated with $\mathrm{pH}$, percentage of clay and CEC values, and positively with carbonate content. When evaluating Freundlich's partitioning coefficient $\left(\mathrm{K}_{\mathrm{f}}\right)$ and distribution coefficient $\left(\mathrm{K}_{\mathrm{d}}\right)$, it can be seen that they are mostly negatively correlated with $\mathrm{pH}$ values, and in case of $\mathrm{Cd}$, with CEC values. Organic matter contents are negatively correlated with percentages of sand values and carbonate contents, and positively with percentages of silt and EC values. Similarly, CEC values are negatively correlated with percentages of sand values and carbonate content and positively with percentages of silt and $\mathrm{EC}$ values. However, the positive correlation between CEC values and $\mathrm{OM}$ content is not statistically significant.
Table 3. Relative sorption capacity (RSC) in percentages.

\begin{tabular}{|c|c|c|c|c|}
\hline \multicolumn{5}{|c|}{ Relative sorption capacity (RSC) (\%) } \\
\hline Profile & Soil horizons & $\mathrm{Cu}$ & $\mathrm{Zn}$ & $\mathrm{Cd}$ \\
\hline \multirow{6}{*}{ Profile 1} & A & 97.68 & 85.01 & 74.86 \\
\hline & $A C$ & 96.13 & 81.49 & 63.45 \\
\hline & $2 \mathrm{Cl}$ & 95.84 & 73.55 & 39.98 \\
\hline & $3 \mathrm{Cl}$ & 88.97 & 76.07 & 46.19 \\
\hline & $4 \mathrm{Clr} / \mathrm{Cl}$ & 88.91 & 77.40 & 47.05 \\
\hline & $5 \mathrm{Cr}$ & 90.18 & 75.38 & 42.42 \\
\hline \multirow{8}{*}{ Profile 2} & A & 49.52 & 29.80 & 25.93 \\
\hline & $2 \mathrm{ACl}$ & 49.21 & 28.14 & 25.06 \\
\hline & $2 \mathrm{AC2}$ & 48.95 & 24.70 & 22.33 \\
\hline & $3 \mathrm{Cl}$ & 48.41 & 20.52 & 17.79 \\
\hline & $3 C 2$ & 48.52 & 21.48 & 16.78 \\
\hline & $4 A C$ & 48.63 & 22.67 & 18.67 \\
\hline & $5 A C$ & 48.30 & 19.78 & 17.20 \\
\hline & $5 C$ & 48.36 & 20.72 & 18.06 \\
\hline \multirow{5}{*}{ Profile 3} & A & 48.01 & 28.29 & 24.11 \\
\hline & $2 \mathrm{Ag}$ & 48.96 & 31.09 & 25.24 \\
\hline & $2 \mathrm{Ag} 2$ & 49.61 & 32.42 & 24.34 \\
\hline & $2 \mathrm{ACg}$ & 49.09 & 29.94 & 22.24 \\
\hline & $3 \mathrm{ACl}$ & 48.20 & 27.60 & 21.24 \\
\hline \multirow{3}{*}{ Profile 4} & A & 48.72 & 27.55 & 25.80 \\
\hline & $2 \mathrm{~B}$ & 41.93 & 17.12 & 18.75 \\
\hline & $3 B C$ & 41.07 & 17.22 & 15.78 \\
\hline
\end{tabular}

For loamic soils (Table 5), results of correlation analysis are different in comparison to siltic soils. RSC for all selected PTMs, as well as $\mathrm{K}_{\mathrm{fs}}$ values, are positively correlated with $\mathrm{pH}$ values $\mathrm{OM}$ and carbonate contents and $\mathrm{EC}$ values. Also, carbonate contents are positively correlated with $\mathrm{OM}$ contents while $\mathrm{CEC}$ values are positively correlated with percentages of silt values.

\section{DISCUSSION}

The highest PTM amounts are retained by the shallowest soil depth range $(0-19 \mathrm{~cm})$ from Profile 1 (Fig. 4, Table 3). RSC values of $\mathrm{Cu}, \mathrm{Zn}$ and $\mathrm{Cd}$ are above $97 \%, 85 \%$ and $75 \%$ respectively at this soil depth range. These results are consistent with results of previous research (RUŽIČIĆ et al., 2016; RUŽIČIĆ \& JAŠARAGIĆ-RAKO, 2017), probably due to the high contents of silt, clay and OM and high CEC values (Table 1). Furthermore, it can be seen that the median value of $\mathrm{Cu}$ sorption is much higher in comparison with the median values for $\mathrm{Zn}$ and $\mathrm{Cd}$ (Fig. 8). The sorption capacity of soils has been found to be affected by several factors, including: $\mathrm{CEC}$, texture, $\mathrm{pH}$, redox potential, clay content and mineralogy, organic matter, Fe and Mn oxides and carbonate content (BRADL, 2004). Our results show increased affinity for sorption (Table 3, Figs. 4 and 5) in topsoil horizons of siltic soils (Profiles 1 and 2), which can be explained by the fact that these soil materials have the highest CEC values and present excellent conditions for the sorption of PTMs. The sorption affinity is not 


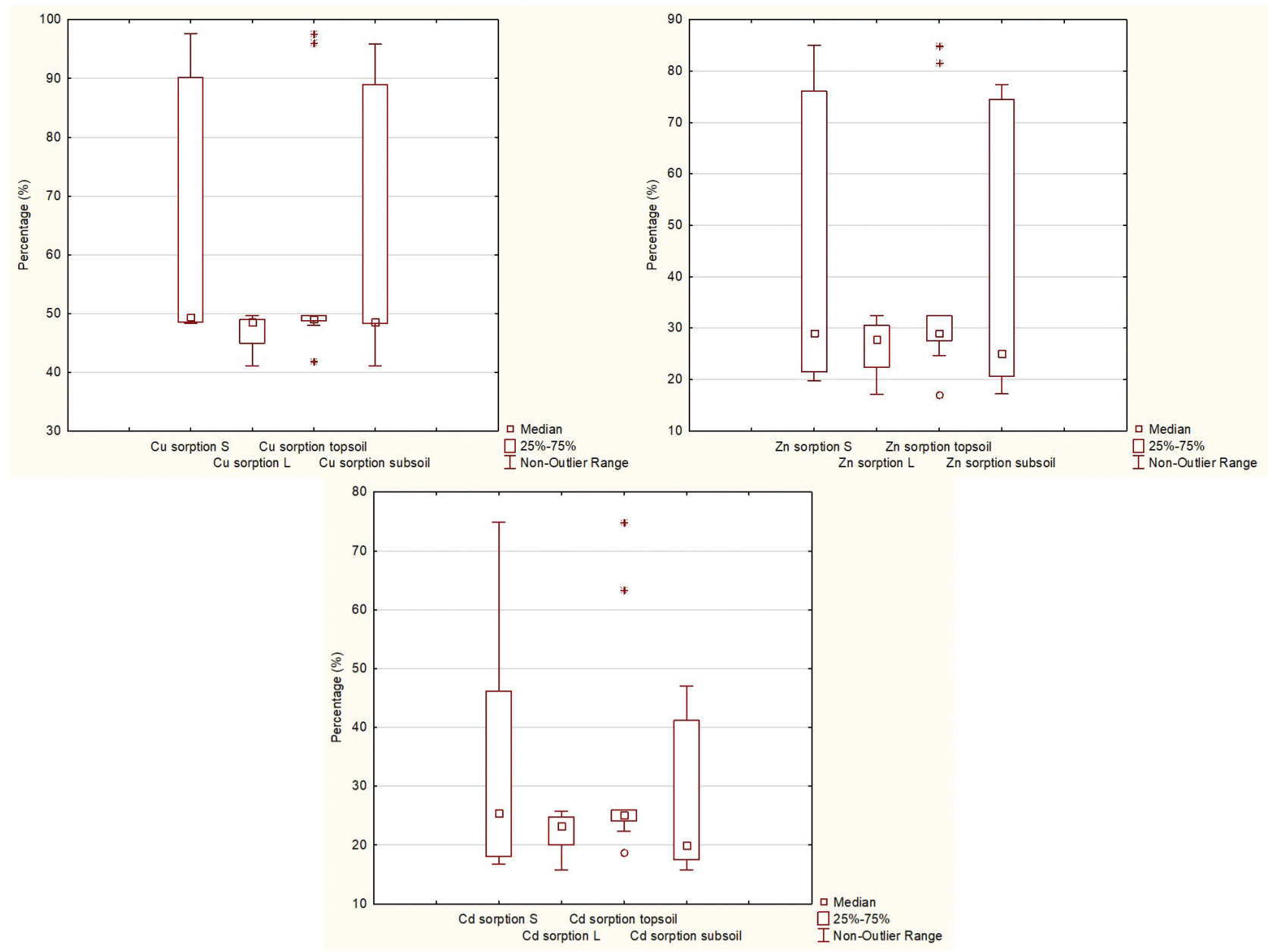

Figure 8. Box-plots of $\mathrm{Cu}, \mathrm{Zn}$ and Cd sorption with respect to siltic soils (S), loamic soils (L), topsoil (shallow) and subsoil (deep) horizons.

changed through soil depth in Profiles 1 and 2 for $\mathrm{Cu}$ and $\mathrm{Zn}$, which is not the case for $\mathrm{Cd}$.

FONTES et al. (2000) observed similar sorption behaviour for PTMs in soils enriched with carbonate minerals. Their results indicated that the presence of carbonates in the soil created new sorption sites and also favoured the precipitation of $\mathrm{Cu}$ and $\mathrm{Zn}$. In the analyzed soils, the presence of carbonate minerals led to an elevated $\mathrm{pH}$ level (Table 1) which may have enhanced PTM

Table 4. Correlation analysis of soil texture parameters, physicochemical characteristics and sorption parameters in siltic soils (significant results at $\mathrm{p}<0.05$ marked in red).

\begin{tabular}{|c|c|c|c|c|c|c|c|c|c|c|c|c|c|c|}
\hline & $\mathrm{pH}$ & Sand & Silt & Clay & OM & CEC & Carbonate & EC & Cu Sorption & Zn sorption & Cd sorption & Cu $K_{d}\left(K_{f}\right)$ & $\mathrm{Zn} \mathrm{K}_{\mathrm{f}}$ & $\mathrm{Cd} \mathrm{K}_{\mathrm{f}}$ \\
\hline $\mathrm{pH}$ & 1.00 & & & & & & & & & & & & & \\
\hline Sand (\%) & 0.22 & 1.00 & & & & & & & & & & & & \\
\hline Silt (\%) & -0.33 & -0.99 & 1.00 & & & & & & & & & & & \\
\hline Clay (\%) & 0.52 & -0.44 & 0.28 & 1.00 & & & & & & & & & & \\
\hline OM (\%) & -0.47 & -0.61 & 0.67 & -0.10 & 1.00 & & & & & & & & & \\
\hline CEC (meq/100 g) & 0.26 & -0.79 & 0.74 & 0.53 & 0.45 & 1.00 & & & & & & & & \\
\hline Carbonate (mass. \%) & 0.21 & 0.88 & -0.90 & -0.21 & -0.59 & -0.81 & 1.00 & & & & & & & \\
\hline $\mathrm{EC}(\mu \mathrm{S} / \mathrm{cm})$ & -0.10 & -0.66 & 0.67 & 0.18 & 0.67 & 0.77 & -0.72 & 1.00 & & & & & & \\
\hline Cu Sorption (\%) & -0.58 & 0.48 & -0.41 & -0.57 & -0.13 & -0.84 & 0.62 & -0.51 & 1.00 & & & & & \\
\hline Zn sorption (\%) & -0.62 & 0.42 & -0.34 & -0.56 & -0.07 & -0.82 & 0.57 & -0.48 & 0.99 & 1.00 & & & & \\
\hline Cd sorption (\%) & -0.69 & 0.14 & -0.07 & -0.42 & 0.15 & -0.56 & 0.35 & -0.20 & 0.91 & 0.93 & 1.00 & & & \\
\hline $\mathrm{Cu} \mathrm{K}_{\mathrm{d}}\left(\mathrm{K}_{\mathrm{f}}\right)(\mathrm{l} / \mathrm{g})$ & -0.42 & -0.17 & 0.25 & -0.38 & 0.44 & 0.03 & -0.09 & 0.35 & 0.34 & 0.30 & 0.46 & 1.00 & & \\
\hline $\mathrm{Zn} \mathrm{K}_{\mathrm{f}}(\mathrm{l} / \mathrm{g})$ & -0.65 & 0.13 & -0.07 & -0.34 & 0.16 & -0.50 & 0.34 & -0.14 & 0.86 & 0.88 & 0.99 & 0.45 & 1.00 & \\
\hline $\mathrm{Cd} \mathrm{K}_{\mathrm{f}}(\mathrm{l} / \mathrm{g})$ & -0.59 & 0.21 & -0.16 & -0.34 & 0.13 & -0.54 & 0.43 & -0.20 & 0.88 & 0.89 & 0.98 & 0.46 & 0.98 & 1.00 \\
\hline
\end{tabular}


Table 5. Correlation analysis of soil texture parameters, physicochemical characteristics and sorption parameters in loamic soils (significant results at $\mathrm{p}<0.05$ marked in red).

\begin{tabular}{|c|c|c|c|c|c|c|c|c|c|c|c|c|c|c|}
\hline & $\mathrm{pH}$ & Sand & Silt & Clay & $\mathrm{OM}$ & CEC & Carbonate & EC & Cu Sorption & Zn sorption & n Cd sorption & $\mathrm{CuK}_{\mathrm{f}}$ & $\mathrm{Zn} \mathrm{K}_{\mathrm{f}}$ & $\mathrm{Cd} \mathrm{K}_{\mathrm{f}}$ \\
\hline $\mathrm{pH}$ & 1.00 & & & & & & & & & & & & & \\
\hline Sand (\%) & -0.04 & 1.00 & & & & & & & & & & & & \\
\hline Silt (\%) & -0.01 & 0.03 & 1.00 & & & & & & & & & & & \\
\hline Clay (\%) & 0.03 & -0.85 & -0.55 & 1.00 & & & & & & & & & & \\
\hline CEC (meq/100 g) & 0.27 & -0.12 & 0.81 & -0.32 & 0.47 & 1.00 & & & & & & & & \\
\hline Carbonate (mass. \%) & 0.63 & -0.42 & 0.43 & 0.12 & 0.85 & 0.53 & 1.00 & & & & & & & \\
\hline $\mathrm{EC}(\mu \mathrm{S} / \mathrm{cm})$ & 0.62 & -0.42 & -0.17 & 0.45 & 0.70 & -0.12 & 0.63 & 1.00 & & & & & & \\
\hline Cu Sorption (\%) & 0.79 & -0.06 & 0.33 & -0.12 & 0.86 & 0.39 & 0.69 & 0.76 & 1.00 & & & & & \\
\hline Zn sorption (\%) & 0.81 & -0.15 & 0.36 & -0.06 & 0.93 & 0.46 & 0.79 & 0.76 & 0.98 & 1.00 & & & & \\
\hline Cd sorption (\%) & 0.61 & 0.07 & 0.60 & -0.37 & 0.74 & 0.63 & 0.52 & 0.42 & 0.89 & 0.86 & 1.00 & & & \\
\hline $\mathrm{CuKK}_{\mathrm{f}}(\mathrm{l} / \mathrm{g})$ & 0.91 & -0.13 & 0.19 & 0.01 & 0.87 & 0.43 & 0.79 & 0.72 & 0.90 & 0.95 & 0.74 & 1.00 & & \\
\hline $\mathrm{Zn} \mathrm{K}_{\mathrm{f}}(\mathrm{l} / \mathrm{g})$ & 0.75 & -0.23 & 0.25 & 0.06 & 0.95 & 0.31 & 0.84 & 0.86 & 0.93 & 0.97 & 0.72 & 0.92 & 1.00 & \\
\hline $\mathrm{Cd} \mathrm{K}_{\mathrm{f}}(\mathrm{l} / \mathrm{g})$ & 0.62 & -0.13 & 0.52 & -0.16 & 0.98 & 0.50 & 0.85 & 0.69 & 0.90 & 0.94 & 0.80 & 0.84 & 0.95 & 1.00 \\
\hline
\end{tabular}

carbonate precipitation reactions. In addition, IMTIAZ et al. (2006) found that most of the added $\mathrm{Zn}$ is held in the $\mathrm{CaCO}_{3}$ pool in alkaline soils, whereas in acidic soils $\mathrm{Zn}$ mostly occurs in exchangeable form. Our sorption data suggest that $\mathrm{Cu}$ and $\mathrm{Zn}$ may precipitate as carbonate phases in the Fluvisols due to calcite dissolution, which was previously explained by SIPOS (2009).

The correlation analysis from Table 4 shows moderate positive correlation between $\mathrm{Cu}, \mathrm{Zn}$ and carbonate content in Profiles 1 and 2 (siltic soils), which suggests similar sorption behaviours of $\mathrm{Cu}$ and $\mathrm{Zn}$, as confirmed by SIPOS (2009). In addition, correlation analysis between $\mathrm{Cd}$ sorption and carbonates shows a lower correlation (0.35), which is not statistically significant and can be attributed to the precipitation of $\mathrm{CdCO}_{3}$ that occasionally occurs in sandy soils with low CEC and organic matter and alkaline $\mathrm{pH}$ (BRADL, 2004).

Freundlich's partitioning coefficient $\left(\mathrm{K}_{\mathrm{f}}\right)$ and distribution coefficient $\left(\mathrm{K}_{\mathrm{d}}\right)$ represent the sorption affinity of the metal cations in solution for the soil solid phase and can be used to characterize the mobility and retention of PTMs in a soil system. Low $\mathrm{K}_{\mathrm{f}}$ and $\mathrm{K}_{\mathrm{d}}$ values indicate that most of the PTMs present in the soil system remain in solution and are available for transport, chemical processes and plant uptake (JALALI \& MOHARRAMI, 2007). In addition, higher values of $\mathrm{K}_{\mathrm{f}}$ and $\mathrm{K}_{\mathrm{d}}$ indicate lower mobility and higher retention or sorption of PTMs in the soil. The distribution coefficient for $\mathrm{Cu}$ (Profile 1) and partitioning coefficients for other PTMs are higher in first two horizons of Profiles 1 and 2 (siltic soils), which is in line with the sorption of PTMs (Table 3). It can be explained with high values of OM and CEC in these topsoil horizons. Although the distribution coefficient $\left(\mathrm{K}_{\mathrm{d}}\right)$ of $\mathrm{Cu}$ is in positive moderate correlation ( 0.44$)$ with the OM content in our study, it is not statistically significant (Table 4). However, it has been shown that the sorption characteristics of $\mathrm{Cu}$ are enriched in soils with higher OM content (MA et al., 2010; ZEMANOVÁ et al., 2014; GONZÂLEZ-COSTA et al., 2017; ELBANA \& SELIM, 2019). Soil organic matter can enhance the adsorption of $\mathrm{Cu}$ by the soils through the formation of complexes between this metal and the active groups of the organic matter (GUO et al., 2006; MINKINA et al., 2017).
The highest PTM amounts in Profile 3 are retained at the third soil depth range $(40-60 \mathrm{~cm})$ (Fig. 6, Table 3). Cu showed retention of $49 \%$, $\mathrm{Zn}$ of $32 \%$, while only $24 \%$ of $\mathrm{Cd}$ is sorbed at this soil depth range. Comparing RSC values among the studied soil profiles, most of the PTMs are retained at the topsoil horizons, which is unusual, but can be explained by the fact that these soil materials consisted of finer particles (at the depth of 40-60 $\mathrm{cm}$ ) and have the highest CEC values and OM content (Table 1). ELBANA et al. (2018) found that soils with high OM and CEC values exhibited strong sorption for PTMs. In addition, correlation analysis from Table 5 confirmed, apparently, strong positive correlation between all PTMs sorption affinity, Freundlich's partitioning coefficient $\left(\mathrm{K}_{\mathrm{f}}\right)$ and $\mathrm{OM}$ content (from 0.74 to 0.98 ). These results suggest that at this soil profile sorption of PTMs is more related to the silt fraction, rather than clay, which corresponds to the results of RUŽIČIĆ et al. (2019b), who found that $\mathrm{Zn}$ is strongly positively correlated with the silt component in loamic soils.

In Profile 4, the sorption pattern is completely different from Profile 3 (Fig. 7, Table 3), with the highest sorption values of all PTMs in the topsoil horizon. Cu sorption capacity is above $48 \%$, $\mathrm{Zn}$ is above $27 \%$, while $26 \%$ of $\mathrm{Cd}$ is sorbed at this soil depth range. From these results it can be seen that $\mathrm{Cd}$ and $\mathrm{Zn}$ have similar sorption affinities. The OM and CEC values are the highest in this soil horizon, which is in correspondence with Profile 3. According to RUŽIČIĆ et al. (2019a), this soil has a minimum content of sand material at subsurface soil depths, which also favours a higher affinity for PTMs sorption. All results suggest that the main physicochemical property of soil for PTM sorption in loamic soils is organic matter.

The result of the sorption experiments in texturally different soils confirmed that soil sorption decreased in the order $\mathrm{Cu}>\mathrm{Zn}$ $>\mathrm{Cd}$, which is consistent with results reported by other authors (COVELO et al., 2008; VIDAL et al., 2009; DIŞLI, 2010; TRAKAL et al., 2012; ELBANA \& SELIM, 2019). The comparison of all PTM sorption isotherms (Figs. 4 to 7) in the analyzed soil profiles revealed that $\mathrm{Cu}$ has the highest sorption affinity, which is confirmed with relevant partitioning and distribution co- 
efficients. This can be also seen in Fig. 8, where the median value for $\mathrm{Cu}$ sorption in both soil groups (siltic and loamic) and at both soil horizons (topsoil and subsoil) is higher than for $\mathrm{Zn}$ and $\mathrm{Cd}$. Alternatively, if sorption of PTMs is evaluated separately, based on soil texture and horizon depth, it can be seen that the analyzed soils have similar median sorption values which is unusual with respect to their genesis and formation. However, a greater variability of sorption is observed in siltic soils and in deeper horizons. Comparable results were obtained by SANGIUMSAK \& PUNRATTANASIN (2014), who reported that all analyzed soils in their research have a similar adsorption capacity.

Our research indicates that $\mathrm{pH}$, carbonate content (minerals) and $\mathrm{OM}$ are the most important soil properties influencing the sorption of analyzed PTMs. All topsoil horizons, with higher sorption affinities, are neutral to slightly alkaline (6.49-7.34). In general, soils with higher $\mathrm{pH}$ indicate better adsorption processes due to reduced concentrations of $\mathrm{H}^{+}$in the solution. Nevertheless, the sample composition and affinity of PTMs also influence the adsorption processes. Therefore, the adsorption capacities of soils increased with increasing $\mathrm{pH}$ value. Soil colloids with a negative charge and PTMs with a positive charge effectively increase the adsorption capacity of soil. According to HE et al. (2020), the adsorption of heavy metals in soils increased with increasing $\mathrm{CaCO}_{3}$ content. In addition, soils with high organic matter and soils with high $\mathrm{pH}$, due to the presence of carbonates, exhibited strong sorption for all heavy metals (ELBANA \& SELIM, 2019). Our sorption data indicates that $\mathrm{Zn}$ and $\mathrm{Cu}$ in siltic soils are mostly affected by $\mathrm{pH}$ and carbonate content due to their precipitation as carbonate phases. This process was documented previously by other studies (IMTIAZ, et al., 2006; SIPOS, 2009; HE et al., 2020).

It is interesting to note that only in topsoil horizons of the analyzed soils were outliers and higher sorption values discovered. RUŽIČIĆ et al. (2019a) found that smaller particles (clay and smaller fraction of silt) prevailed at the topsoil horizons of analyzed soils. These extreme values can be partly attributed to higher CEC and OM values and mainly clay minerals at these soil depths.

Clay mineralogy and also $\mathrm{Fe}$ and Mn oxyhydroxides can contribute to higher sorption values in topsoil horizons of analyzed soils. According to previous studies (VERTAČNIK et al., 1997; RUŽIČIĆ et al., 2019b), these types of soils in the research area have increased contents of chlorites and vermiculites which are clay minerals with a higher affinity for ionic sorption. In addition, RUŽIČIĆ et al. (2016) found increased content of Fe and Mn oxyhydroxides in subsurface soil depths of Fluvisols.

The Zagreb aquifer system, where groundwater is naturally stored, is currently under threat due to decreasing water quantity and increasing concentrations of pollutants such as PTMs (NAKIĆ et al., 2013). Our results reveal that sorption of PTMs is well represented in the first three depth bands of the analyzed soils. From an environmental point of view, PTMs are retained in the upper soil horizons and their transport to the saturated zone is limited. This finding is favourable for the protection of groundwater within the Zagreb aquifer system. Zinc and copper probably do not present toxicity to soils and groundwater in the study area. This is not the case for $\mathrm{Cd}$, which is the most mobile of all three analyzed PTMs. Our results indicate the relatively high leaching potential of cadmium from soil to groundwater, which is consistent with the results of previous researches conducted in the Zagreb area (ROMIĆ, 2002; ROMIĆ \& ROMIĆ, 2003) that show increased concentration of cadmium along the investigated soil profiles. Accordingly, future research of the behaviour of PTMs in soil and groundwater of the Zagreb aquifer system should be focused on characterization of pollution sources and transport of $\mathrm{Cd}$ at depth in order to assess the risk of groundwater contamination.

\section{CONCLUSIONS}

The maximum values of Freundlich's partitioning coefficient $\left(\mathrm{K}_{\mathrm{f}}\right)$ and distribution coefficient $\left(\mathrm{K}_{\mathrm{d}}\right)$ were determined for the first three depth ranges of the studied soils for all analyzed PTMs. Our results indicate that sorption of PTMs is influenced more by soil physicochemical characteristics at different soil depths than by soil type per se, which is confirmed with the higher affinity of $\mathrm{Zn}$ and $\mathrm{Cd}$ bonding in the topsoil horizons.

All analyzed soils showed adsorption capacity in the order of $\mathrm{Cu}>\mathrm{Zn}>\mathrm{Cd}$. Zinc and copper probably do not present a toxicity threat to soils and the Zagreb aquifer. This is not the case for $\mathrm{Cd}$ which is the most mobile of the three analyzed PTMs. Also, it has been shown that the sorption capacity values of all PTMs have greater variability in siltic soils and in the subsoil horizons. This suggests that sorption of PTMs is influenced more by the physicochemical characteristics at different soil depths than by soil type.

Accordingly, regular monitoring of $\mathrm{Cd}$ concentrations with depth in soils of the Zagreb aquifer system is needed in order to quantify leaching of cadmium through the soil to the groundwater and to evaluate the risk of groundwater contamination by moderate to highly mobile PTMs.

\section{REFERENCES}

ADRIANO, D.C. (2001): Trace elements in terrestrial environments: biogeochemistry.Springer, New York, 867 p.

APPEL, C. \& MA, L. (2002): Concentration, pH, and surface charge effects on cadmium and lead sorption in three tropical soils.- Journal of Environmental Quality, 31, 581-589. doi: 10.2134/jeq2002.5810

BESNARD, E., CHENU, C. \& ROBERT, M. (2001): Influence of organic amendments on copper distribution among particle-size and density fractions in Champagne vineyard soils.- Environmental Pollution, 112, 329-337. doi: 10.1016/S02697491(00)00151-2

BONTEN, L.T.C., ROMKENS, P.F.A.M. \& BRUS, D.J. (2008): Contribution of heavy metal leaching from agricultural soils to surface water loads.- Environmental Forensics, 9, 252-257. doi: 10.1080/15275920802122981

BRADL, H.B. (2004): Adsorption of heavy metal ions on soils and soils constituents.Journal of Colloid and Interface Science, 277/1, 1-18. doi: 10.1016/j. jcis.2004.04.005

COVELO, E.F., MATÍAS J.M., VEGA F.A., REIGOSA M.J. \& ANDRADE M.L. (2008): A tree regression analysis of factors determining the sorption and retention of heavy metals by soil.- Geoderma, 147, 75-85. doi: 10.1016/j.geoderma.2008.08.001

DIŞLI, E. (2010): Batch and column experiments to support heavy metals (Cu, $\mathrm{Zn}$ and $\mathrm{Mn}$ ) transport modeling in alluvial sediments between the Mogan lake and the Eymir Lake Gölbaşi, Ankara.- Groundwater Monitoring and Remediation, 30/3, 125-139. doi: 10.1111/j.1745-6592.2010.01302.x

DURN, G., MIKO, S., ČOVIĆ, M., BARUDŽIJA, U., TADEJ, N., NAMJESNIKDEJANOVIĆ, K. \& PALINKAŠ, L. (1999): Distribution and behaviour of selected elements in soil developed over a historical $\mathrm{Pb}-\mathrm{Ag}$ mining site at $\mathrm{Sv}$. Jakob, Croatia.- Journal of Geochemical Exploration, 67/1-3, 361-376. doi: 10.1016/ S0375-6742(99)00064-3

ELBANA, T.A., SELIM, H.M., AKRAMI, N., NEWMAN, A., SHAHEEN, S.M. \& RINKLEBE, J. (2018): Freundlich sorption parameters for cadmium, copper, nickel, lead, and zinc for different soils: Influence of kinetics.-Geoderma, 324, 80-88. doi: 10.1016/j.geoderma.2018.03.019

ELBANA, T.A. \& SELIM, H.M. (2019): Modeling of cadmium and nickel release from different soils.- Geoderma, 338, 78-87. doi: 10.1016/j.geoderma.2018.11.041

FAO (2006): Guidelines for Soil Description, $4^{\text {th }}$ edition. FAO, Rome.

FONTES, M.P.F., DE MATOS, A.T., DA COSTA, L.M. \& NEVES, J.C.L. (2000): Competitive adsorption of zinc, cadmium, copper, and lead in three highly weathered Brazilian soils.- Communications in Soil Science and Plant Analysis, 31, 2923-2958. doi: 10.1080/00103620009370640 
GONZÂLEZ-COSTA, J.J., REIGOSA, M.J., MATÍAS J.M. \& FERNÁNDEZ-COVELO, E. (2017): Analysis of the Importance of Oxides and Clays in $\mathrm{Cd}, \mathrm{Cr}, \mathrm{Cu}, \mathrm{Ni}$, $\mathrm{Pb}$ and $\mathrm{Zn}$ Adsorption and Retention with Regression Trees.- PLoS ONE, 12/1, 1-25. doi: 10.1371/journal.pone. 0168523

GUO X.Y., ZHANG, S.Z., SHAN, X.Q., LUO, L., PEI, Z.G., ZHU, Y.G., LIU, T., XIE, Y.N. \& GAULT, A. (2006): Characterization of $\mathrm{Pb}, \mathrm{Cu}$, and $\mathrm{Cd}$ adsorption on particulate organic matter in soil.- Environmental Toxicology Chemistry, 25/9, 2366-2373. doi: 10.1897/05-636r.1

HE, G., ZHANG, Z., WU, X., CUI, M., ZHANG, J. \& HUANG, X. (2020): Adsorption of Heavy Metals on Soil Collected from Lixisol of Typical Karst Areas in the Presence of $\mathrm{CaCO}_{3}$ and Soil Clay and Their Competition Behavior--Sustainability, 12, 7315. doi: $10.3390 /$ sul 12187315

HEAD, K.H. (1992): Manual of Soil Laboratory Testing.- Pentech press, London, 388 p. HOUGH, R.L. (2010): Copper and Lead.- In: HOODA, P.S. (eds.): Trace Elements in Soils. Wiley-Blackwell Publishing: West Sussex, United Kingdom, 441-461. doi: 10.1002/9781444319477.ch18

IMTIAZ, M., ALLOWAY, B.J., ASLAM, M., MEMON, M.Y., KHAN, P., SIDDIQUI, S. \& SHAH, S.K.H. (2006): Zinc sorption in selected soils.- Communications in Soil Science and Plant Analysis, 37, 1675-1688. doi: 10.1080/00103620600710330

ISO 10390 (2005): Soil quality-determination of pH.- International Organisation for Standardisation, Switzerland.

ISO 13536 (1995): Soil quality-determination of the potential cation exchange capacity and exchangeable cations using barium chloride solution buffered at $\mathrm{pH}=8,1$.International Organisation for Standardisation: Geneva, Switzerland.

IUSS Working Group WRB. (2014): World Reference Base for Soil Resources 2014: International Soil Classification System for Naming Soil and Creating Legends for Soil Maps; World Soil Resources Report; FAO: Rome, Italy, p.106.

JALALI, M. \& MOHARRAMI, S. (2007): Competitive adsorption of trace elements in calcareous soils of Western Iran.- Geoderma, 140, 156-163. doi: 10.1016/j.geoderma.2007.03.016

LICHNER, L., DLAPA, P., SIR, M., CIPAKOVA, A., HOUSKOVA, B., FASKO, P. \& NAGY, V. (2006): The fate of cadmium in field soils of the Danubian lowland.Soil \& Tillage Research, 85, 154-165. doi: 10.1016/j.still.2005.01.011

MA, L., XU, R. \& JUN, J. (2010): Adsorption and desorption of $\mathrm{Cu}(\mathrm{II})$ and $\mathrm{Pb}$ (II) in paddy soils cultivated for various years in the subtropical China.- Journal of Environmental Sciences, 22/5, 689-695. doi: 10.1016/S1001-0742(09)60164-9

MARTINEZ, C.E. \& MOTTO, H.L. (2000): Solubility of lead, zinc and copper added to mineral soils.- Environmental Pollution, 107, 153-158. doi: 10.1016/S02697491(99)00111-6

MINKINA, T.M., PINSKII, D.L., BAUER, T.V., NEVIDOMSKAYA, D.G., MANDZHIEVA, S.S. \& SUSHKOVA, S.N. (2017): Sorption of Cu by chernozems in southern Russia.- Journal of Geochemical Exploration, 174, 107-112. doi: 10.1016/j.gexplo.2016.06.002

NAKIĆ, Z., RUŽIČIĆ, S., POSAVEC, K., MILEUSNIĆ, M., PARLOV, J., BAČANI, A. \& DURN, G. (2013): Conceptual model for groundwater status and risk assessment-case study of the Zagreb aquifer system.- Geologia Croatica, 66/1, 55-77. doi: $10.4154 / \mathrm{GC} .2013 .05$

NAN, Z., LI, J., ZHANG, J. \& CHENG, G. (2002): Cadmium and zinc interactions and their transfer in soil-crop system under actual field conditions.- Science of the Total Environment, 285, 187-195. doi: 10.1016/S0048-9697(01)00919-6

OECD (2000), Test No. 106: Adsorption -- Desorption Using a Batch Equilibrium Method, OECD Guidelines for the Testing of Chemicals, Section 1, OECD Publishing, Paris, https://doi.org/10.1787/9789264069602-en

PIETRZAK, U. \& McPHAIL, D.C. (2004): Copper accumulation, distribution and fractionation in vineyard soils of Victoria, Australia.- Geoderma, 122, 151-166. doi: 10.1016/j.geoderma.2004.01.005

ROMIĆ, M. \& ROMIĆ, D. (2003): Heavy metals distribution in agricultural topsoils in urban area.- Environmental Geology, 43, 795-805. doi: 10.1007/s00254-0020694-9

RULEY, A.T., SHARMA, N.C., SAHI, S.V., SHREE, S.R. \& SAJWAN, K.S. (2006): Effects of lead and chelators on growth, photosynthetic activity and $\mathrm{Pb}$ uptake in Sesbaniadrummondii grown in soil.- Environmental Pollution, 144, 11-18. doi: 10.1016/j.envpol.2006.01.016

RUŽIČIĆ, S., MILEUSNIĆ, M., POSAVEC, K., NAKIĆ, Z., DURN, G. \& FILIPOVIĆ, V. (2016): Water flow and solute transport model of potentially toxic elements through unsaturated zone at regional wellfield Kosnica.- Hydrological Processes, 30/22, 4113-4124. doi: 10.1002/hyp.10914

RUŽIČIĆ, S. \& JAŠARAGIĆ-RAKO, T. (2017): Multielement sorption of cadmium, zinc, copper and lead onto a Fluvisol profile at the Stara Loza site, Croatia.- International Journal of Environment and Pollution, 62/1, 63-73. doi: 10.1504/ IJEP. 2017.088188

RUŽIČIĆ, S., KOVAČ, Z., PERKOVIĆ, D., BAČANI, L. \& MAJHEN, LJ. (2019a): The Relationship between the Physicochemical Properties and Permeability of the Fluvisols and Eutric Cambisols in the Zagreb Aquifer, Croatia.-Geosciences, 9/10, 416. doi: $10.3390 /$ geosciences 9100416

RUŽIČIĆ, S., KOVAČ, Z. \& BOROVČAK, T. (2019b): Possible Influence of Agriculture on an Unsaturated Zone in Croatia.- Polish Journal of Environmental Studies, 28/6, 4341-4349. doi: 10.15244/pjoes/99305

SANGIUMSAK, N. \& PUNRATTANASIN, P. (2014): Adsorption Behavior of Heavy Metals on Various Soils.- Polish Journal of Environmental Studies, 23/3, 853-865.

SELIM, H.M., BUCHTER, B., HINZ, C. \& MA, L. (1992): Modeling the Transport and Retention of Cadmium in Soils: Multireaction and Multicomponent Approaches.Soil Science Society of American Journal, 56/4, 1004-1015. doi: 10.2136/ sssaj1992.03615995005600040002x

SEUNTJENS, P., TIREZ, K., ŠIMU゚NEK, J., VAN GENUCHTEN, MTH., CORNELIS, C. \& GEUZENS, P. (2001): Aging effects on cadmium transport in undisturbed contaminated sandy soil column.- Journal of Environment Quality, 30, 1040-1050. doi: $10.2134 /$ jeq2001.3031040x

SHAHEEN, S.M., TSADILAS, C.D., MITSIBONAS, T. \& TZOUVALEKAS, M. (2009): Distribution coefficient of copper in different soils from Egypt and Greece.- Communications in Soil Science and Plant Analysis, 40, 214-226. doi: $10.1080 / 00103620802625625$

SIPOS, P. (2009): Single element and competitive sorption of copper, zinc and lead onto a Luvisol profile.- Open Geosciences volume, 1/4, 404-415. doi: 10.2478/ v10085-009-0035-2

SMOLDERS, E. \& MERTENS, J. (2013): Cadmium.-In: ALLOWAY, B.J. (eds.): Heavy Metals in Soils: Trace Metals and Metalloids in Soils and Their Bioavailability. Springer, Dordrecht, Heidelberg, New York, London, 283-311.

SOLLITTO, D., ROMIĆ, M., CASTRIGNANO, A., ROMIĆ, D. \& BAKIĆ, H. (2010): Assessing heavy metal contamination in soils of the Zagreb region (Northwest Croatia) using multivariate geostatistics.- Catena, 80, 182-194. doi: 10.1016/j. catena.2009.11.005

TRAKAL, L., KOMÁREK, M., SZÁKOVÁ, J., TLUSTOŠ, P., TEJNECKÝ, V. \& DRÁBEK, O. (2012): Sorption Behavior of Cd, $\mathrm{Cu}, \mathrm{Pb}$, and $\mathrm{Zn}$ and Their Interactions in Phytoremediated Soil.- International Journal of Phytoremediation, 14/8, 806-819. doi: 10.1080/15226514.2011.628714

VEGA, F.A., COVELO, E.F. \& ANDRADE, M.L. (2008): A versatile parameter for comparing the capacities of soil for sorption and retention of heavy metals dumped individually or together: Results for cadmium, copper and lead in twenty soil horizons.- Journal of Colloid and Interface Science, 327/2, 275-286. doi: 10.1016/j. jcis.2008.08.027

VELIĆ, J. \& SAFTIĆ, B. (1991): Subsurface spreading and facies characteristics of middle Pleistocene deposits between Zaprešić and Samobor-- Geological Bulletin, 44, 69-82.

VELIĆ, J. \& DURN, G. (1993): Alternating lacustrine-marsh sedimentation and subaerial exposure phases during quaternary: Prečko, Zagreb, Croatia.- Geologia Croatica, 46/1, 71-90.

VERTAČNIK, A., BARIŠIĆ, D., MUSANI, LJ., PROHIĆ, E. \& JURAČIĆ, M. (1997): Exchangeable fraction of elements in alluvial sediments under waste disposal site (Zagreb, Croatia).- Journal of Radioanalytical and Nuclear Chemistry, 218/1, 45-52. doi: $10.1007 / \mathrm{bf} 02033972$

VIDAL, M., SANTOS, M.J., ABRAO, T., RODRÍGUEZ, J. \& RIGOL, A. (2009): Modelling competitive sorption in a mineral soil.- Geoderma, 149, 189-198. doi: 10.1016/j.geoderma.2008.11.040

XIONG, X., STAGNITTI, F., TUROCZY, N., ALLINSON, G., LI, P., NIEBER, J., STEENHUIS, T.S., PARLANGE, J.Y., LEBLANC, M., ZIOGAS, A.K., FERREIRA, A.J.D. \& KEIZER, J.J. (2005): Competitive sorption of metals in water repellent soils: Implications for irrigation recycled water-- Australian Journal of Soil Research, 43/3, 351-356. doi: 10.1071/SR04086

ZEMANOVÁ, V., TRAKAL, L., OCHECOVÁ, P., SZÁKOVÁ, J. \& PAVLÍKOVÁ, D. (2014): A Model Experiment: Competitive Sorption of $\mathrm{Cd}, \mathrm{Cu}, \mathrm{Pb}$ and $\mathrm{Zn}$ by Three Different Soils.- Soil and Water Research, 9/3, 97-103. doi: 10.17221/50/2013-SWR 